\title{
COMMENTS
}

\section{RESENTENCING DEFENDANTS AND THE PROTECTION AGAINST MULTIPLE PUNISHMENT}

\author{
Michael P. Doss $\dagger^{\dagger}$
}

It has been said that trouble seldom comes singly for the criminal defendant. ${ }^{1}$ At trial she is often faced with a number of separate criminal charges. When such a defendant is convicted and sentenced, an appeal may result in the reversal of some but not all of the counts. The sentences attached to the reversed counts necessarily fall as well. Under these circumstances, the Courts of Appeals for the Second, Third, Sixth, and Seventh Circuits have held that the constitutional guarantee against double jeopardy ${ }^{2}$ does not preclude vacating the sentences on the remaining counts and remanding the case to the trial court for resentencing-expressly allowing for an increase of the sentences on the affirmed counts. ${ }^{3}$ Thus, in United States $v$.

$†$ B.A. 1982, University of Oregon; J.D. Candidate, 1986, University of Pennsylvania. The author wrote this Comment while a student at the University of Pennsylvania Law School.

1 See Standards for CRIminal Justice § 18-4.5 commentary at 292 (1980).

2 "IN]or shall any person be subject for the same offence to be twice put in jeopardy of life or limb ...." U.S. ConST. amend. V. The double jeopardy clause is applied to the states through the fourteenth amendment. Benton v. Maryland, 395 U.S. 784, 793-96 (1969).

See United States v. Mourad, 729 F.2d 195, 203-04 (2d Cir.), cert. denied, 105 S. Ct. 180 (1984); McClain v. United States, 676 F.2d 915, 918 (2d Cir.), cert. denied, 459 U.S. 879 (1982); United States v. Pinto, 646 F.2d 833, 838 (3d Cir.), cert. denied, 454 U.S. 816 (1981); United States v. Moore, 710 F.2d 270, 270-71 (6th Cir.), cert. denied, 104 S. Ct. 497 (1983); United States v. Covelli, 738 F.2d 847, 862 (7th Cir.), cert. denied, 105 S. Ct. 211 (1984); United States v. Jefferson, 714 F.2d 689, 706-07 (7th Cir. 1983).

Remanding for harsher sentencing following the reversal of certain counts has arisen in three distinct settings. In Mourad, the Second Circuit vacated sentences under criminal conspiracy counts because the offenses merged with the defendant's "continuing criminal enterprise" conviction. See Mourad, 729 F.2d at 202. Offenses "merge" when it is determined that the legislature did not intend to allow for separate convictions and punishment-for instance if one offense is a lesser included offense of the other, or perhaps when the offenses are committed during the same criminal transaction. In Mourad the court remanded the "continuing criminal enterprise" conviction and stated that "the district court may consider whether to increase the . . sentence." Id. at 204.

In United States v. Busic, 639 F.2d 940 (3d Cir.), cert. denied, 452 U.S. 918 (1981), the defendant was originally sentenced to twenty years imprisonment under a 
Moore $e^{4}$ the defendant, after receiving consecutive sentences of fifteen and twenty-five years imprisonment for bank robbery and kidnapping convictions, was resentenced to forty years on the kidnapping conviction alone after the bank robbery charge was held improper on appeal. ${ }^{5}$

The Supreme Court has not addressed the issue of whether increasing sentences on remaining valid counts is barred by the double jeopardy clause. ${ }^{6}$ Prior to the Court's opinion in United States $v$. DiFrancesco, ${ }^{7}$ however, it was generally assumed in the federal courts that the double jeopardy protection against multiple punishments for the same offense prohibited such an increase in sentence. ${ }^{8}$

The sharp change in opinion by the courts of appeals ${ }^{9}$ after the

federal "enhancement statute" for using a gun to commit a felony. See id. at 943. Enhancement statutes allow for additional punishment when an underlying offense includes certain aggravating circumstances. After the defendant's initial conviction and sentencing, the Supreme Court held that Congress did not intend to provide for enhancement when "the predicate felony statute contain[ed] its own enhancement provision." Busic v. United States, 446 U.S. 398, 404 (1980). The Third Circuit then vacated not only the improper enhancement sentence, but also the sentence on the underlying felony conviction. The court held that on remand the trial judge was free to impose a greater sentence on the remaining conviction. See United States v. Busic, 639 F.2d at 953.

Finally, in Pinto the defendant was convicted of bank robbery and of making false representations to a bank. Such charges are independent-they neither merge nor depend on the existence of a predicate offense. Pinto had been sentenced to five years imprisonment on the bank robbery charge and five years probation on the false representations charge. Pinto, 646 F.2d at 834. The Third Circuit held that Pinto's actions did not fall within the bank robbery statute and reversed the conviction. See id. at 837 . The court affirmed the other conviction and, following Busic, remanded for resentencing. See id. at 838. Given this second chance, the trial court imposed a two-year prison term plus a $\$ 5000$ fine. See United States v. Pinto, No. $79-00133$ (E.D. Pa. Nov. 2, 1981), aff d, 681 F.2d 810 (3d Cir.) (unpublished judgment order), cert. denied, 459 U.S. 879 (1982).

+ 710 F.2d 270 (6th Gir.), cert. denied, 104 S. Ct. 497 (1983).

- See id. at 270.

- See United States v. Henry, 709 F.2d 298, 309 (5th Cir. 1983) (en banc); McClain v. United States, 676 F.2d 915, 918 (2d Cir.), cert. denied, 459 U.S. 879 (1982).

7449 U.S. 117 (1980).

${ }^{8}$ See United States v. Jefferson, 714 F.2d 689, 706 (7th Gir. 1983); United States v. Henry, 709 F.2d 298, 309 (5th Cir. 1983) (en banc); United States v. DiFrancesco, 604 F.2d 769, 783-85 (2d Cir. 1979), rev'd, 449 U.S. 117 (1980); United States v. Fredenburgh, 602 F.2d 1143, 1148 (3d Cir. 1979); United States v. Turner, 518 F.2d 14, 16 (7th Cir. 1975); United States v. Welty, 426 F.2d 615, 619 (3d Cir. 1970); United States v. Sacco, 367 F.2d 368, 369 (2d Cir. 1966).

- This judicial shift is best illustrated through a pair of Third Circuit opinions. In United States v. Fredenburgh, 602 F.2d 1143 (3d Cir. 1979), the court stated that

"[a]dded punishment under a valid sentence simply because the defendant has successfully shown the invalidity of the sentence under another count is a plain violation of the [double jeopardy clause]. It may not be justified because the sentencing judge would have imposed the higher penalty if he had been aware of the invalidity of the sentence imposed on the other counts." 
issuance of DiFrancesco results from a misunderstanding of the constitutional values that underlie the prohibition of multiple punishment and inform the scope of its protections. This Comment argues that the protection against multiple punishment serves two purposes. First, it restricts judicial power to determine the initial punishment and to increase the punishment at a later time. Second, the multiple punishment bar protects the defendant's interest in finality. That is, it respects the defendant's interest in having the ordeal of sentencing over once and for all to avoid the strain of uncertainty and delay.

Part I of this Comment describes the development of the double jeopardy clause and the protection against multiple punishment. Part II concludes that increasing sentences on surviving counts of a multicount conviction presents a multiple punishment issue. Part III analyzes the scope of the multiple punishment bar as informed by the values that underlie the rule and concludes that the rule forbids increased sentences on remand when the underlying conviction is undisturbed.

\section{Double Jeopardy and the Multiple Punishment Bar: A General Description}

Protection from twice being placed in jeopardy represents "one of the oldest ideas found in western civilization."10 Over 2000 years ago Demosthenes declared, "[T] he laws forbid the same man to be tried twice on the same issue....."11 Centuries later Blackstone repeated, "[It is a] universal maxim of the common law of England that no man is to be brought into jeopardy of his life, more than once, for the same offense."12 Yet despite its age the protection from double jeopardy is

Id. at 1148 (quoting United States v. Welty, 426 F.2d 615, 619 (3d Cir. 1970)).

Two years later the court found that

[t]there is nothing in the history or the policies of the Double Jeopardy Glause that justifies the denial of resentencing when the sentence has been spread erroneously over counts that have been declared invalid. On the other hand, resentencing under such circumstances should reduce the possibility of disparate and irrational sentencing.

United States v. Busic, 639 F.2d 940, 947-48 (3d Gir.), cert. denied, 452 U.S. 918 (1981); see also cases cited supra note 3.

${ }_{10}$ Bartkus v. Illinois, 359 U.S. 121, 151 (1959) (Black, J., dissenting). "The constitutional provision had its origin in the three common-law pleas of autrefois acquit, autrefois convict, and pardon. These three pleas prevented the retrial of a person who had previously been acquitted, convicted, or pardoned for the same offense." United States v. Scott, 437 U.S. 82, 87 (1978). For a history of double jeopardy protections, see M. Friedland, Double Jeopardy 5-15 (1969); J. Sigler, Double Jeopardy: The Development of a Legal and Social Policy 1-37 (1969).

111 Demosthenes 589 (J. Vance trans. 1962), quoted in United States v. Jenkins, 490 F.2d 868, 870 (2d Cir. 1973), affd, 420 U.S. 358 (1975).

124 W. Blackstone, Commentaries *335. 


\section{"one of the least understood . . . provisions of the Bill of Rights."1s}

The wording of the double jeopardy clause is short and obscure, but it has grown to embody no fewer than three distinct constitutional protections. The Supreme Court's "favorite saying about double jeopardy" 14 goes as follows: "It protects against a second prosecution for the same offense after acquittal. It protects against a second prosecution for the same offense after conviction. And it protects against multiple punishments for the same offense."15 Thus, if resentencing defendants to increased punishment is to be barred by the double jeopardy clause, the prohibition must be found within this trio of protections. Although a strong argument can be made that resentencing to harsher punishment is barred by the protection against a second prosecution following acquittal, ${ }^{18}$ this Comment deals exclusively with the protection against

13 Whalen v. United States, 445 U.S. 684, 699 (1980) (Rehnquist, J., dissenting). "That its application has not proved to be facile or routine is demonstrated by acknowledged changes in direction or in emphasis." United States v. DiFrancesco, 449 U.S. 117,127 (1980) (citations omitted).

14 Westen, The Three Faces of Double Jeopardy: Reflections on Government Appeals of Criminal Sentences, 78 Mich. L. REV. 1001, 1062 (1980).

15 North Carolina v. Pearce, 395 U.S. 711,717 (1969) (footnotes omitted); accord United States v. DiFrancesco, 449 U.S. 117, 129 \& n.10 (1980).

The general purposes underlying the double jeopardy clause were described by the Supreme Gourt in Green v. United States, 355 U.S. 184 (1957):

The underlying idea ... is that the State with all its resources and power should not be allowed to make repeated attempts to convict an individual for an alleged offense, thereby subjecting him to embarrassment, expense and ordeal and compelling him to live in a continuing state of anxiety and insecurity, as well as enhancing the possibility that even though innocent he may be found guilty.

Id. at 187-88.

16 In Green v. United States, 355 U.S. 184 (1957), the Supreme Court held that if the legislature has divided an offense into separate degrees of seriousness, then a conviction for a lesser degree acts as an implicit acquittal of all greater degrees. See id. at 190. Thus, a conviction for second degree murder acts as an acquittal for the charge of first degree murder. Once acquitted, the defendant can never be retried or convicted for the same offense. See id.

The implicit acquittal argument is easily adapted to sentencing decisions: When a particular sentence is chosen from a range of authorized penalties, it is argued that " "the judge or jury is implicitly "acquitting" the defendant of a greater penalty, just as the jury in Green implicitly acquitted ... the accused of a greater degree of the same offense." " North Carolina v. Pearce, 395 U.S. 711, 728 n.1 (1969) (Douglas, J., concurring) (quoting Van Alstyne, In Gideon's Wake: Harsher Penalties and the "Successful" Criminal Appellant, 74 YaLE L.J. 606, 635 (1965)).

In Pearce Justice Harlan also argued that the Green rationale applied equally to sentencing decisions:

In each instance, the defendant was once subjected to the risk of receiving a maximum punishment, but it was determined by legal process that he should receive only a specified punishment less than the maximum. . . . [T] he concept ... of an 'implicit acquittal' of the greater offense . . . applies equally to the greater sentence: in each case it was determined at the former trial that the defendant or his offense was of a certain limited 
multiple punishment.

degree of 'badness' or gravity only, and therefore merited only a certain limited punishment.

Id. at 746 (Harlan, J., concurring in part, dissenting in part) (citations omitted).

The consequence of a particular sentence acting as an implicit acquittal of all harsher sentences would be that once a sentence is imposed it could not later be increased without violating the double jeopardy clause.

The implicit acquittal argument for sentencing decisions has, however, been explicitly rejected by the Court. In United States v. DiFrancesco, 440 U.S. 117 (1980), the Court upheld a statute providing for appeals of sentences by the government under specific circumstances. See $i d$. at 142-43. The Court stated that a sentence does not have the "qualities of constitutional finality that attend an acquittal," id. at 134, and thus "the imposition of sentence does not operate as an implied acquittal of any greater sentence." Id. at 136 n.14.

Yet the implicit acquittal argument for sentencing decisions is not dead. The Court resurrected it in Bullington v. Missouri, 451 U.S. 430 (1981), during the same term as DiFrancesco. In Bullington the Court held that, because Missouri's capital sentencing procedure sufficiently resembled a trial of guilt or innocence, a jury sentence of life imprisonment in that state served as an acquittal of "whatever was necessary to impose the death sentence." "Id. at 445 (1981) (quoting State ex rel. Westfall v. Mason, 594 S.W.2d 908, 922 (Mo. 1980) (Bardgett, C.J., dissenting)). Thus, when a sentencing procedure sufficiently resembles a trial, the sentence imposed will act as an implicit acquittal of all greater sentences.

In Arizona v. Rumsey, 104 S. Ct. 2305 (1984), the Court described three characteristics of a capital sentencing procedure that made it "sufficiently" like a trial on guilt or innocence to warrant double jeopardy protections. First, the discretion of the sentencing judge was limited-the only two sentencing options were death and life imprisonment. See id. at 2310 . Second, the judge was required to make findings, pursuant to statutory standards, with respect to aggravating and mitigating circumstances, and the aggravating circumstances had to be shown beyond a reasonable doubt. See id. Finally, the sentencing hearing provided an opportunity to submit additional evidence and present arguments. See id.

Sentencing guideline systems, such as the recently enacted Sentencing Reform Act of 1984, Pub. L. No. 98-473, 1984 U.S. Code CoNG. \& AD. NEws (98 Stat.) 1987 (to be codified primarily in scattered sections of 18 and 28 U.S.C.), may allow for an expansion of the Bullington "implicit acquittal" reasoning into areas other than capital sentencing procedures. The Sentencing Reform Act will require in each case a determination of the mitigating and aggravating circumstances involved in the particular offense, see id. at 2020 (to be codified at 28 U.S.C. $\S$ 994(c)), as well as the characteristics of the particular defendant, see id. (to be codified at 28 U.S.C. $\S 994(d)$ ). Once such a determination is made, the court will be guided to the specific range and type of sentence to impose. See id. at 2019 (to be codified at 28 U.S.C. $\$$ 994(a)).

The information required for these sentencing decisions will be obtained from the trial record, from a sentencing hearing, and from a probation officer's presentence report. See FED. R. CRIM. P. 32(a)(1), (c)(1). The sentencing hearing will provide an opportunity for both the government and the defendant to comment on the probation officer's findings in the presentence report and to urge their own views of the proper sentence applicable to the case. See FED. R. GRIM. P. 32(a)(1). Thus, sentencing procedures under the new Federal Sentencing Reform Act will closely resemble the capital sentencing procedures described in Bullington and Rumsey.

The question remains, however, whether the Court will ever be willing to extend this reasoning to noncapital sentencing procedures. In the Bullington opinion the Court did not mention the uniqueness of the death sentence as a rationale for its holding. Yet the unique nature of the death penalty often underlies the Court's reasoning in capital cases, even if it is not stated. See, e.g., Rummel v. Estelle, 445 U.S. 263, 272 (1980). 
The Supreme Court has considered only a handful of cases involving the application of the multiple punishment bar to alterations of original sentences. In Ex parte Lange ${ }^{17}$ the Court held that the defendant could not be resentenced after having satisfied one of the authorized punishments for his offense. ${ }^{18}$ The sentencing judge in Lange was barred by the protection against multiple punishment from imposing a new sentence that in effect would have exceeded the maximum sentence allowed by the relevant statute. ${ }^{19}$

In Bozza v. United States ${ }^{20}$ the Court held that if the initial sentence is lower than the statutory minimum it may be corrected without breaching the multiple punishment bar even though the correction results in increased punishment. ${ }^{21}$ The Court distinguished this increase in punishment from the situation in Lange by the fact that the sentencing court had no authority to impose the initial illegal sentence and indeed was required by law to correct it. ${ }^{22}$

North Carolina v. Pearce ${ }^{23}$ presented the question whether the double jeopardy clause permits a court to sentence a defendant whose initial conviction was vacated because of trial error to greater punishment following retrial. ${ }^{24}$ The Court held that a necessary corollary to the power to retry the defendant is the ability, "upon the defendant's reconviction, to impose whatever sentence may be legally authorized."25 The new conviction and sentence did not constitute multiple punishment since "the original conviction has, at the defendant's behest, been wholly nullified and the slate wiped clean."26

Finally, in United States v. DiFrancesco ${ }^{27}$ the Court held that the double jeopardy clause did not prohibit Congress from enacting a statute that provided for governmental appeals of sentences imposed upon "dangerous special offenders" ${ }^{28}$ under specific circumstances. ${ }^{29}$ In deciding that the multiple punishment protection was not violated, the

Thus, the mere resemblance of noncapital sentencing guidelines to the procedures at issue in Bullington might not persuade the Court to view a sentence imposed under those guidelines as an implied acquittal of harsher sentences.

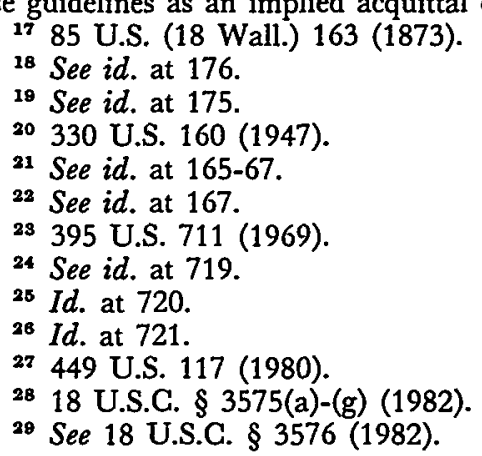


Court found that the defendant had no legitimate expectations of the finality of the initial sentence where "Congress has specifically provided that the sentence is subject to appeal."

Our understanding of the multiple punishment bar would be well served if the holdings of these cases could be weaved together under one coherent doctrine. It is more useful to develop the boundaries of the multiple punishment protection to determine if resentencing defendants on remand falls within these boundaries, than it is merely to determine whether resentencing defendants is more similar to Lange than DiFrancesco.

\section{Sentencing in Multiple Count Convictions}

In order to determine whether the multiple punishment bar prohibits increasing legal sentences on remand, it is important first to determine what is meant by "increased sentences" in the context of multicount convictions. A successful appeal of one of the counts will generally result in a reduction of the aggregate sentence initially imposed, even after resentencing on the affirmed counts. In United States v. Pinto ${ }^{31}$ for example, the defendant's initial sentence was five years imprisonment on a bank robbery conviction and five years probation on a conviction for making false representations to a bank. ${ }^{32}$ After a reversal of the bank robbery conviction the defendant was resentenced on the false representations offense to two years imprisonment and a $\$ 5000$ fine. $^{33}$ The original aggregate sentence was thus reduced while the sentence on the particular offense was increased.

From these facts it could be argued that the defendant is not subjected to an increased punishment if the total punishment after resentencing does not exceed the original total sentence. ${ }^{34}$ If the defendants's

so DiFrancesco, 449 U.S. at 139.

31 646 F.2d 833 (3d Cir.), cert. denied, 454 U.S. 816 (1981).

92 See id. at 834 .

3s United States v. Pinto, No. 79-00133 (E.D. Pa. Nov. 2, 1981), aff d, 681 F.2d 810 (3d Cir.) (unpublished judgment order), cert. denied, 459 U.S. 879 (1982).

34 Cf. United States v. Henry, 709 F.2d 298, 303 (5th Cir. 1983) (en banc) (government argued that, despite increased sentences on certain counts, the reduction in sentence for the entire criminal transaction precluded a challenge based on the multiple punishment bar). If the new sentence were to exceed the aggregate original sentence, a strong argument could be made that the increase would violate the due process clause. North Carolina v. Pearce, 395 U.S. 711 (1969), holds that the due process clause requires that any increase in the aggregate sentence be based upon new objective information concerning conduct by the defendant and that the reasons for any increase "affirmatively appear." 395 U.S. at 726 . These requirements are necessary to insure that a defendant's exercise of the right to appeal is not deterred by a fear of vindictiveness on the part of the sentencing judge. See id. at 725 . 
"sentence" has not been increased following resentencing, then the punishment surely cannot be deemed multiple.

The argument that the defendant is not suffering increased punishment treats the aggregate sentence imposed in a multicount conviction as a general sentence for an entire criminal transaction rather than as specific sentences for specific offenses. ${ }^{36}$ The assumption is that a sentencing judge determines an aggregate sentence for the entire criminal event and splits this aggregate sentence among the specific counts of conviction..$^{38}$

This argument certainly has a practical appeal. It cannot be doubted that judges often determine sentences for specific counts with an eye on a desired aggregate sentence. ${ }^{37}$ Indeed, the rationale for remanding sentences on the remaining counts is that the judge intended the criminal behavior to be punished by the aggregate sentence and that this intention was foiled by the reversal of one of the underlying counts of conviction. ${ }^{38}$ This was the position of the Court of Appeals for the Third Gircuit in United States v. Busic ${ }^{39}$ when it stated that the double jeopardy clause does not bar increasing the sentence on the remaining counts "when the sentence has been spread erroneously over counts that have been declared invalid." 40

Yet the view that a defendant is not suffering increased punishment when the aggregate sentence is lowered ignores the fact that sentences are authorized only insofar as they result from a conviction for the violation of a particular federal statute. As the Court of Appeals for the Fifth Circuit stated in United States $v$. Henry, "11 "[A] federal 'sentence' is not general or transactional. It is the specific consequence of a specific federal statute." 42

A federal court's authority to impose a particular criminal punishment is derived solely from Congress's decision to prescribe certain punishments for certain criminal behavior. ${ }^{43}$ While it may seem artifi-

ss See United States v. Henry, 709 F.2d 298, 303 (5th Gir. 1983) (en banc).

se See id.

37 "Available evidence suggests that criminal sentencing decisions already are based heavily upon actual offense behavior as distinguished from the formal offense of conviction." Schulhofer, Due Process of Sentencing, 128 U. PA. L. REv. 733, 757 (1980).

s8 See, e.g., United States v. Jefferson, 714 F.2d 689, 707 \& n.34 (7th Cir. 1983); United States v. Busic, 639 F.2d 940, 947 (3d Cir.), cert. denied, 452 U.S. 918 (1981).

s9 639 F.2d 940 (3d Cir.), cert. denied, 452 U.S. 918 (1981).

$10 I d$. at 948.

11709 F.2d 298 (5th Cir. 1983) (en banc).

42 Id. at 310.

43 See, e.g., Whalen v. United States, 445 U.S. 684, 689 (1980) ("[T]he power to define criminal offenses and to prescribe the punishments to be imposed upon those found guilty of them . . . resides wholly with the Congress.") (citation omitted); Rum- 
cial to divide a criminal transaction into separate counts, each punishable by a separate sentence, this is the structure imposed on the federal courts by Congress. The federal Sentencing Reform Act of $1984^{44}$ supports this view of sentences by requiring the trial court to consider the characteristics of "each offense for which a term of imprisonment is being imposed"45 when determining sentences following multiple count convictions.

Thus, although a defendant's aggregate sentence may be reduced after resentencing, the punishment for a particular offense will still be increased. The reduction of the aggregate sentence is the result of a reversal of some of the original counts of conviction-"it is the lawful result of a successful challenge to an illegal sentence."166 Multiple punishment analysis therefore must focus on a particular sentence imposed for a specific offense. A defendant's "punishment" is increased whenever the sentence attached to a particular count is increased. The question remains, however, whether the multiple punishment bar protects a defendant from such increases in punishment.

\section{Resentencing Defendants and the Multiple PUNISHMENT BAR}

\section{A. The Scope of the Multiple Punishment Bar}

The Supreme Court has often stated that the double jeopardy clause protects a criminal defendant from multiple punishments for the same offense, ${ }^{47}$ but the Court has been unclear on the proper scope of this protection. At one time it was argued that the multiple punishment bar contained an independent standard "for defining the existence of a criminal offense and for establishing the maximum permissible sentence for such an offense."18 Under such a standard the Court would be able to strike down a statute whenever it provided for punishment in excess of what the double jeopardy clause defined to be the maximum sentence

mel v. Estelle, 445 U.S. 263,274 (1980).

14 Act of Oct. 12, 1984, Pub. L. No. 98-473, 1984 U.S. Code Cong. \& AD. NEws (98 Stat.) 1987 (to be codified primarily in scattered sections of 18 and 28 U.S.C.). added).

45 Id. $\S 212,98$ Stat. at 2000 (to be codified at 18 U.S.C. $\S 3584$ (b)) (emphasis

${ }^{46}$ United States v. Henry, 709 F.2d 298, 303 (5th Cir. 1983) (en banc).

47 See, e.g., Ohio v. Johnson, 104 S. Ct. 2536, 2540 (1984); Missouri v. Hunter, 459 U.S. 359, 366 (1983); United States v. DiFrancesco, 449 U.S. 117, 129 (1980); Whalen v. United States, 445 U.S. 684, 688 (1980); North Carolina v. Pearce, 395 U.S. 711, 717 (1969).

48 Westen, supra note 14, at 1024; accord Simpson v. United States, 435 U.S. 6, 11-13 (1978); Jeffers v. United States, 432 U.S. 137, 155 (1977) (plurality opinion). 
for the underlying offense.

This argument has since been repudiated by the Court. ${ }^{49}$ Its major weakness is that the Constitution does not contain a clear standard for defining criminal offenses or for determining the maximum permissible length of criminal sentences. ${ }^{50}$ By determining maximum sentences for various criminal offenses, the courts would be intruding on the legislature's exclusive power to "define criminal offenses and to prescribe the punishments to be imposed." 1

More recently the Supreme Court stated that the multiple punishment bar "is designed to ensure that the sentencing discretion of courts is confined to the limits established by the legislature." ${ }^{\text {2 }}$ Under such a standard a punishment becomes multiple when the court imposes a sentence in excess of what the legislature intended to authorize for a specific criminal act. For example, a sentencing court would violate the multiple punishment protection if it imposed a sentence of twenty-five years imprisonment for a particular offense when the statutory maximum sentence was twenty years.

The Supreme Court has left open the possibility of a broader reading of the multiple punishment protection. In Whalen $v$. United States $^{\mathbf{6 3}}$ the Court stated that the protection "at the very least precludes federal courts from imposing consecutive sentences unless authorized by Congress to do so." ${ }^{24}$ This invitation to interpret the protection more broadly has been ignored by a number of courts of appeals. These courts have stated that the prohibition of punishment in excess of the statutory maximum is the only protection afforded the criminal defendant by the multiple punishment bar. ${ }^{55}$

Lower courts have misperceived the proper scope of the multiple punishment bar because the Supreme Court has not clearly identified the values that inform the rule. To examine these values, it is helpful to turn to the Court's first pronouncement of the rule, over a century ago,

49 See Missouri v. Hunter, 459 U.S. 359, 368 (1983); Whalen v. United States, 445 U.S. 684,688 (1980).

so See Westen, supra note 14 , at 1024-25. The eighth amendment prohibits the state from imposing sentences that are "grossly disproportionate to the severity of the crime," Rummel v. Estelle, 445 U.S. 263, 271 (1980), but outside of the context of capital punishment "successful challenges to the proportionality of particular sentences have been extremely rare." Id. at 272 .

s1 Whalen v. United States, 445 U.S. 684, 689 (1980).

s2 Ohio v. Johnson, 104 S. Ct. 2536, 2541 (1984).

53445 U.S. 684 (1980).

o4 Id. at 689 (emphasis added).

${ }^{65}$ See, e.g., United States v. Mourad, 729 F.2d 195, 203 (2d Cir.), cert. denied, 105 S. Ct. 180 (1984); United States v. Jones, 722 F.2d 632, 637 (11th Cir. 1983); United States v. Busic, 639 F.2d 940, 951-52 (3d Cir.), cert. denied, 452 U.S. 918 (1981). 
in Ex parte Lange: $:^{56}$

If there is anything settled in the jurisprudence of England and America, it is that no man can be twice lawfully punished for the same offense. . . . [T]here has never been any doubt of [this rule's] entire and complete protection of the party when a second punishment is proposed in the same court, on the same facts, for the same statutory offence. ${ }^{57}$

The facts of Lange certainly did not forebode its seminal character. The defendant was convicted of appropriating mail bags for his own use-a violation of federal law punishable by "imprisonment for not more than one year or a fine of not . . . more than two hundred dollars." takenly sentenced Lange to one year in prison and a $\$ 200.00$ fine. $^{59}$ The fine was promptly paid. After being shown his mistake the judge vacated the prior sentence and resentenced Lange to a one-year imprisonment. ${ }^{60}$ The Supreme Court held that it was a violation of the double jeopardy clause to impose punishment again after the defendant had already satisfied one of the authorized alternative punishments: "[T]he Constitution was designed as much to prevent the criminal from being twice punished for the same offence as from being twice tried for it." ${ }^{\prime \prime 1}$

The basic issue before the Court in Lange was a "question of the power of courts over their judgments once rendered in criminal cases." ${ }^{62}$ This concern with judicial power was clearly expressed by the Court when it spoke of the inability of the judge to resentence Lange: "[T]he inexpediency of placing such a power in the hands of any tribunal is manifest." ${ }^{\text {s3 }}$ Thus, the multiple punishment bar acted as a restriction upon judicial power. It barred the judge's abuse of power in imposing additional punishment after the defendant had fully served an authorized punishment for the offense.

But the protection against multiple punishment is concerned with more than just restricting abuses of judicial power. The Court in Lange also spoke of the double jeopardy "principle that no man shall more than once be placed in peril of legal penalties upon the same accusa-

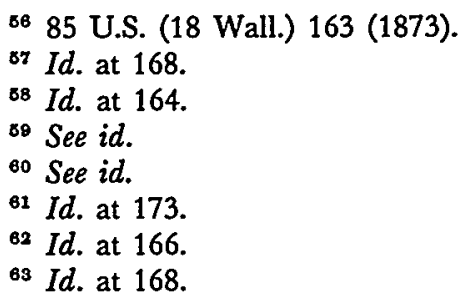


tion." ${ }^{\text {"64 }}$ Thus, the multiple punishment protection also values the defendant's interest in finality-the interest in not being subject to the "ordeal and ... anxiety and insecurity" proceeding.

The Lange opinion hence evidenced two primary concerns that inform the rule barring multiple punishment. First, the Court was concerned with abuses of judicial power in sentencing. Second, the Court was concerned with the defendant's interest in finality.

Despite the references in Lange to the constitutional values being furthered by the multiple punishment bar, the scope of the opinion is unclear. The sentencing judge in Lange attempted to impose punishment greater than the maximum authorized by statute. ${ }^{66}$ Such an illegal sentence was a clear abuse of judicial power. It can therefore easily be argued that Lange stands only for the proposition that the multiple punishment doctrine bars punishment in excess of that permitted by law. ${ }^{67}$ If the multiple punishment doctrine does no more than bar these illegally excessive sentences, then resentencing defendants to harsher penalties would not implicate the prohibition of multiple punishment. The double jeopardy clause would merely require that the judge keep the substitute sentence within statutory guidelines. The question thus becomes whether punishment may be "multiple" even though the sentence is within legislated limits.

As one commentator stated, "One cannot know whether a defendant is being punished twice without knowing whether he has yet been fully punished once, and one cannot know whether a defendant has been punished once without identifying the law that governs sentences for particular conduct." $"$ As A legislature clearly may authorize punishment of imprisonment, fine, and public service for a single criminal offense without it being deemed "multiple" punishment under the Constitution. Such a sentencing provision would be within the legislature's exclusive power to "prescribe crimes and determine punishments."69 A judge would not be restricted by the multiple punishment bar from imposing a sentence pursuant to such a statute. ${ }^{\text {7o }}$

64 Id. at 173 (emphasis added).

6s Green v. United States, 355 U.S. 184, 187 (1957).

Be See Lange, 85 U.S. (18 Wall.) at 175.

67 See United States v. DiFrancesco, 449 U.S. 117, 139 (1980). For instance, if Congress had made the theft of mail bags punishable by both a fine and a prison term, then the defendant in Lange would have been unable to complain about the original sentence on multiple punishment grounds.

${ }^{68}$ Westen, supra note 14, at 1024.

${ }^{69}$ Ohio v. Johnson, 104 S. Ct. 2536, 2541 (1984).

${ }^{70}$ See United States v. DiFrancesco, 449 U.S. 117, 139 (1980). 
Yet the multiple punishment bar would be rendered meaningless by a reading that it protects only against the imposition of sentences in excess of legislated limits. The bar would amount to no more than a test of the statutory legality of the sentence. The Supreme Court would not review multiple punishment claims involving state prosecutions because the construction of a state statute by the state's highest court is not subject to review. ${ }^{71}$ In addition, even in cases involving federal law there would be no need for the Court to reach the constitutional issue of multiple punishment: such decisions could be based purely on statutory construction. ${ }^{72}$ Given the Supreme Court's penchant for avoiding constitutional questions when a decision may be rendered on other grounds, ${ }^{73}$ the multiple punishment bar would thus seem doomed to extinction. It is therefore difficult to imagine how a constitutional protection that has endured for over a century would merely provide the unexceptional rule that a judge cannot impose a sentence beyond legislated limits.

In an attempt to give the multiple punishment bar some real force, Professor Westen argues that it should act as a "presumption against finding that domestic law intends multiple offenses and multiple punishment, a presumption that can be overcome only by 'clear and unmistakable' evidence that the domestic law intends offenses and sentences to be cumulated." ${ }^{\prime 74}$ Under Westen's view, even if a particular criminal act arguably constitutes more than one criminal offense, the multiple punishment bar would require that the sentencing judge presume that the legislature intended the act to constitute only one offense and authorize only one sentence. The multiple punishment bar would thus become a constitutional rule of statutory construction. This view finds support in recent Court opinions that require a clear showing of contrary legislative intent before cumulative punishment is allowed. ${ }^{75}$ The sentiments behind such a rule are already evidenced by the Court's presumption of lenity in construing criminal laws ${ }^{78}$ - that is, a defendant

21 See Missouri v. Hunter, 459 U.S. 359, 368 (1983); Mullaney v. Wilbur, 421 U.S. 684, 689 (1975); Murdock v. City of Memphis, 87 U.S. (20 Wall.) 590, 631 (1875); C. Wright, Handbook of the Law of Federal Courts 747 (4th ed. 1983).

72 See Whalen v. United States, 445 U.S. 684, 696 (1980) (White, J., concurring); id. at 702 (Rehnquist, J., dissenting).

${ }^{73}$ See, e.g., Simpson v. United States, 435 U.S. 6, 11-12 (1978); Hagans v. Lavine, 415 U.S. 528, 549 (1974); Ashwander v. TVA, 297 U.S. 288, 346-47 (1936) (Brandeis, J., concurring).

74 Westen, supra note 14, at 1026 (footnotes omitted) (quoting Iannelli v. United States, 420 U.S. 770,791 (1975)).

${ }^{75}$ See Missouri v. Hunter, 459 U.S. 359, 368 (1983); Whalen v. United States, 445 U.S. 684, 695 (1980).

${ }^{76}$ See Bell v. United States, 349 U.S. 81, 83 (1955). 
should be punished only to the extent that the punishment is unambiguously authorized by the legislature.

Westen's reading of multiple punishment protections is too restrictive. If one followed his presumption rule, resentencing defendants to harsher penalties on the remaining counts would not implicate the prohibition of multiple punishment any more than if the prohibition merely barred illegally excessive sentences. It would require only that the judge keep the substitute sentence within statutory guidelines. Westen believes that this is the only formulation of the multiple punishment rule that will give the protection some real force without unduly intruding upon the legislature's exclusive power to define criminal offenses and prescribe punishment. ${ }^{77}$ The Supreme Court is also fearful of constructing the rule so as to tread too deeply into this area of "legislative prerogative."78

This analysis loses sight of the values that inform the multiple punishment bar. It is clear from Lange that the protection against multiple punishment was born not so much from a suspicion of legislative power but from a suspicion of judicial power. ${ }^{79}$ Congress could have authorized both imprisonment and a fine in Lange-the point is that it did not and that the judge exceeded his authority in attempting to impose both penalties.

In order to serve the purposes of the multiple punishment bar, one does not need to construct a rule that would intrude on the legislature's prerogative to prescribe punishment for particular offenses. Rather, the multiple punishment rule may be fashioned to act as both a protection against abuses of judicial power in sentencing and a protection of the defendant's interest in finality.

In the context of resentencing, the judicial abuse feared is vindictiveness against a defendant for having successfully attacked part of a multicount conviction. Such vindictiveness must not play a part in the newly increased sentences on the valid counts. ${ }^{80}$ The Supreme Court has noted that " $t]$ he existence of a retaliatory motivation would ...

77 See Westen, supra note 14, at 1027.

78 Rummel v. Estelle, 445 U.S. 263, 274 (1980) (involving eighth amendment challenge to sentence).

${ }_{79}$ This concern with judicial power is also found in the rule that the authority to impose punishment is granted wholly by statute- "[f]or, if judgments were to be the private opinions of the judge, men would then be slaves to their magistrates . . . 4 W. Blackstone, Commentaries *371. These worries, when coupled with the defendant's interest in finality, were at least partly responsible for the common-law rule that a trial court could not increase an earlier imposed legal sentence. See 4 WHARTON's Criminal Procedure $\S 611$ (C. Torcia 12th ed. 1976).

${ }^{80}$ In North Carolina v. Pearce, 395 U.S. 711 (1969), the Court held that vindictive sentencing was a violation of the due process clause. See $i d$. at 725. 
be extremely difficult to prove in any individual case,"81 but that vindictive sentencing can be prevented by requiring that any increase in punishment be based on "objective information concerning identifiable conduct on the part of the defendant occurring after the time of the original sentencing proceeding."

When a defendant is being resentenced, however, there is unlikely to be any new "objective information concerning identifiable conduct on the part of the defendant" that a sentencing judge can point to as a rationale for increasing the original sentence. The new sentence is imposed by the same judge based on the trial record for the same criminal offense. ${ }^{83}$ Thus, the judge must point to her own subjective intent in the initial sentencing proceeding as a rationale for increasing the sentence. The judge must argue that she mistakenly placed "low" sentences on the remaining counts of conviction under the belief that the original aggregate sentence would be served. Although such an explanation is certainly plausible, it is difficult, if not impossible, to prove. There does not appear to be any way to protect against vindictive sentencing in this context short of barring increases in sentences altogether.

A multiple punishment rule that protects defendants from the possibility of vindictive sentencing and protects their finality interests would therefore bar subsequent increases in final legal sentences when the underlying conviction is undisturbed. This rule would require merely that a sentencing judge be bound by her initial sentencing decision. It assumes that the court will initially impose punishment that it deems commensurate with the criminal liability of the defendant on the particular offenses of conviction. Thus, the final legal sentence imposed by a judge would establish a judicial maximum-any increase of the sentence by the same court for the same offense would constitute multiple punishment in violation of the double jeopardy clause.

The requirement that the original sentence be final and legal acknowledges the legislature's power to authorize various sentences and sentencing procedures without contravening the multiple punishment bar. Thus, if the initial sentence is illegal because it is lower than the statutory minimum, the bar would not prohibit the correction of the sentence even though the sentence is increased-such an increase is required as a matter of law, not as a matter of judicial discretion. In addition, if Congress has specifically provided for governmental appeal

${ }^{81}$ Id. at 725 n.20.

82 Id. at 726.

${ }^{83}$ See United States v. Busic, 639 F.2d 940, 950 (3d Cir.), cert. denied, 452 U.S. 918 (1981). 
of a sentence, as in United States $v$. DiFrancesco, ${ }^{84}$ then the initial sentence is not final, and the bar does not prohibit a subsequent increase.

\section{B. Supreme Court Support for a Rule Barring Enhanced Punishment on Remand}

A bar on increasing legal sentences on remand also finds support in the dictum of a number of Supreme Court opinions. In United States v. Benz $z^{85}$ the Court held that a court has the power to reduce a sentence imposed earlier in the same judicial term. The Court explained that

[t]he distinction that the court during the same term may amend a sentence so as to mitigate the punishment, but not so as to increase it, is . . . based . . . upon the ground that to increase the penalty is to subject the defendant to double punishment for the same offense in violation of the [double jeopardy clause] ....8

In Reid v. Covert" the Gourt acknowledged its earlier holding "that the President or commanding officer had power to return a case to a court-martial for an increase in sentence." ${ }^{\prime 88}$ The Court added, however, that "[i]f the double jeopardy provisions of the Fifth Amendment were applicable such a practice would be unconstitutional." Justice Rehnquist, who placed himself with the majority in DiFrancesco, stated in his dissent in Whalen that the double jeopardy clause "prevents a sentencing court from increasing a defendant's sentence for any particular statutory offense, even though the second sentence is within the limits set by the legislature."90 These statements, along with the Lange decision, led to the general belief prior to DiFrancesco that enhancing punishment following the imposition of valid final sentences was prohibited by the multiple punishment bar. ${ }^{91}$

In DiFrancesco the Court was faced with the question whether Congress could specifically authorize an appeal of a sentence by the government without violating the double jeopardy clause. ${ }^{92}$ The

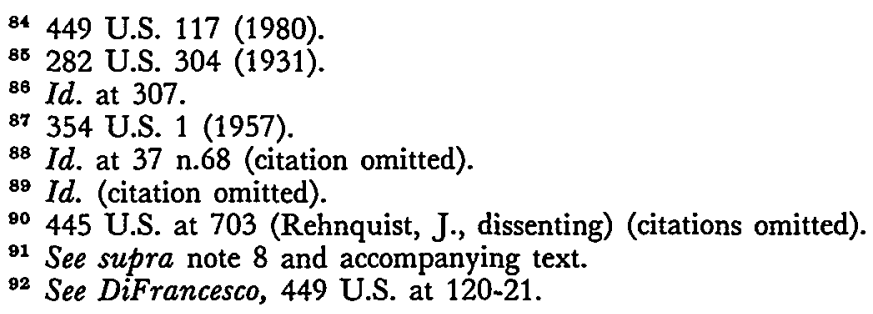


DiFrancesco Court quickly rid itself of the multiple punishment claim. It asserted that the multiple punishment bar protects a defendant against receiving a greater sentence than the legislature has authorized. ${ }^{93}$ Since Congress had expressly authorized the governmental appeal of the sentence in DiFrancesco, however, the guarantee against multiple punishment was not violated. ${ }^{94}$ The Court stated that the statute creating the government's right to appeal the initial sentence "establish[es] at the most a two-stage sentencing procedure."9s Thus, the sentence was not considered final until after the sentence had been reviewed on appeal or the time for appeal had expired. ${ }^{96}$ This led the Court to state that the defendant had no legitimate expectation of finality when a statute provided for a later increase in his sentence. ${ }^{97}$

Yet the simple conclusion in DiFrancesco that the multiple punishment bar was not violated does not apply in the multiple punishment analysis of enhancing final legal sentences on remand. No similar statute exists to authorize the subsequent increase in punishment. ${ }^{98}$ Hence,

93 See id. at 139.

84 See id.

${ }^{95}$ Id. at 140 n.16.

${ }^{86}$ The Court noted that "the original bill introduced in Congress specifically stated that the sentence was not to be considered final until the disposition of review or until the expiration of the time for appeal." Id.

${ }_{97}$ See $i d$. at 137, 139. Two courts of appeals have focused on this language as the DiFrancesco holding. In United States v. Jones, 722 F.2d 632 (11th Gir. 1983), the court stated that, when the original sentence is legal and the statute does not provide for appellate review, the defendant's expectations of finality are legitimate and the double jeopardy clause bars a later increase in sentence. Id. at 638-39. The Ninth Circuit, in United States v. Wingender, 711 F.2d 869 (9th Cir. 1983), also seemed to limit DiFrancesco to situations in which the defendant's expectations are not legitimate, such as those involving an obviously erroneous original sentence. In Wingender the defendant was sentenced to a term to run consecutively with his state sentence. In fact there was no state sentence, only a previous federal sentence. The court held that correcting the obvious error did not violate the double jeopardy clause. See id. at 870-71.

${ }_{98}$ See United States v. Henry, 709 F.2d 298, 309-10 (5th Cir. 1983) (en banc). If such a statute did exist, it could be argued that Congress, as opposed to the courts, could constitutionally allow for resentencing on the remaining counts of a multicount conviction. Such a result would seem to follow from the Difrancesco Court's broad endorsement of the power of a legislature to authorize a subsequent increase of a legal sentence. There are three responses to this argument. First, it must be noted that the statute upheld in DiFrancesco authorized punishment that was "clear and specific," 449 U.S. at 139 (citing 18 U.S.C. $\$ \S 3575-3576$ (1982)), and allowed for governmental appeal only when the original sentence was "clearly erroneous" or constituted an abuse of discretion, 449 U.S. at 120 n.2 (quoting 18 U.S.C. $§ 3576$ (1982)). It is doubtful that a blanket congressional approval of resentencing on remand would be read as a "clear and specific" remedy for a "clearly erroneous" initial sentence.

Second, the DiFrancesco opinion rests on the view that a defendant's interest in finality is not harmed if the defendant knows that the sentence is not final until the deadline for governmental appeal has passed. If the government wishes to appeal a sentence of a dangerous special offender, it must do so "at least five days before expiration of the time for taking a review . . . by the defendant." 18 U.S.C. $\S 3576$ (1982), 
the sentences in the resentencing cases are final-they were not made subject to later increase by a specific statute. At least three Justices agree that the DiFrancesco analysis is limited to the situation in which Congress has expressly authorized an increase in sentence. ${ }^{90}$

In reaching its decision in DiFrancesco, the Court did not proceed with an analysis of the specific purposes of the multiple punishment bar, but such an analysis aids in explaining the decision and in distinguishing it from a situation in which a defendant is resentenced on remand. First, there is little or no fear of an abuse of judicial power when the increased sentence follows an appeal by the government that has been expressly authorized by statute. Unlike the situation in resentencing, the defendant is being sentenced by a new court and has not committed any act that would provoke vindictiveness.

Second, when the legislature has provided for a subsequent increase in the initial sentence, the defendant's finality interest is not injured as greatly as in a resentencing situation in which no such increase in sentence has been authorized by statute. In this sense the statute has

quoted in DiFrancesco, 449 U.S. at 120 n.2. Even if one accepts the Court's view that the interests of a dangerous special offender in finality are not harmed by section 3576 , it is not difficult to distinguish the interests of a defendant in the resentencing context. If Congress allowed for resentencing following reversal of some counts of a multicount conviction, it could be years before all appeals were exhausted and the defendant assured that the initial sentence would not be increased. DiFrancesco does not foreclose the possibility that a court would strike down a statute that resulted in years, rather than days, of anxiety.

Third, congressional approval of resentencing does not remove the danger of judicial vindictiveness. Whether a trial judge is permitted to resentence based on a judicial rule or a statute, there is a very real danger that the sentence will be increased in retaliation for the defendant's successful appeal of the other counts. Such vindictiveness is a violation of the due process clause. See supra notes 80-82 and accompanying text. Even though an increased sentence on remand is not necessarily vindictive, a statute permitting resentencing may violate the multiple punishment bar due to the danger of vindictive sentencing coupled with the harm to the defendant's interest in finality.

${ }^{99}$ See Ralston v. Robinson, 454 U.S. 201, 224 n.3 (1981) (Stevens, Brennan \& O'Connor, JJ., dissenting). The present membership of the Court might well have decided DiFrancesco differently. The retirement of Justice Stewart, who joined the DiFrancesco opinion, leaves four justices on the present Court who joined in the opinion and four who dissented. Justice O'Connor, the new member of the court, has already expressed her view of the limitations of DiFrancesco. See id.

In addition, the statute involved in DiFrancesco provided for the review of a sentence only to the extent that it was "clearly erroneous" or constituted an abuse of discretion. See 18 U.S.C. $\$ 3756$ (1982), quoted in DiFrancesco, 449 U.S. at 120 n.2. "A sentence which is the product of an 'abuse of discretion' under prevailing legislative standards is as unlawful as a sentence which violates the explicit terms of a sentencing statute." Westen, supra note 14, at 1044 n.157. Thus, the Difrancesco Court could have simply followed Bozza v. United States, 330 U.S. 160 (1947), in which the Court held that the correction of an illegal sentence does not violate the multiple punishment bar. See id. at 166-67. In DiFrancesco the sentence was unlawful as applied to the particular case, while in Bozza the sentence was illegal on its face. The Court did not choose this route, however. 
conditioned the defendant's expectations of finality. Thus, looking to the purposes of the multiple punishment protection, it is evident that DiFrancesco does not provide the same multiple punishment problems as when a defendant is being resentenced following the successful appeal of certain counts.

The decisions in North Carolina v. Pearce ${ }^{100}$ and Bozza v. United States $^{101}$ are also consistent with the rule against increasing legal sentences on remand when the underlying conviction remains intact. In Pearce the Court held that a defendant whose conviction was overturned for trial error may be sentenced to a term of imprisonment following reconviction that is longer than the term imposed following the initial conviction. ${ }^{102}$ The Court rested its view "upon the premise that the original conviction has, at the defendant's behest, been wholly nullified and the slate wiped clean."10s

Thus, a reconvicted defendant cannot point to her initial sentence and successfully claim a violation of the multiple punishment rule, because the Court refuses to acknowledge that the initial conviction and sentence ever existed. Perhaps it seems a bit absurd to accept this judicial fiction, but the fiction does have a purpose: the defendant should not be allowed to claim in the same breath that the initial conviction was tainted by trial error but that the initial sentence from this tainted trial should nonetheless act as a ceiling. A conviction and sentence necessarily stand and fall together-it is incongruous to argue one should be maintained while the other is overturned. Defendants may be seen as forfeiting their rights to have the court treat the initial sentence as a ceiling if they successfully appeal the initial conviction. ${ }^{104}$

The decision in Bozza v. United States virtually mimics Pearce from the perspective of the protection against multiple punishment. In Bozza the trial court mistakenly imposed a sentence of imprisonment on the operator of a still when the applicable statute required a sentence of imprisonment and a fine. ${ }^{108}$ The trial court later corrected its mistake, and the Supreme Court held that the defendant was not twice put in jeopardy. ${ }^{108}$ The Court in Bozza stated that "[t]he Constitution does not require that sentencing should be a game in which a wrong move by the judge means immunity for the prisoner." ${ }^{107}$ Doubtless the

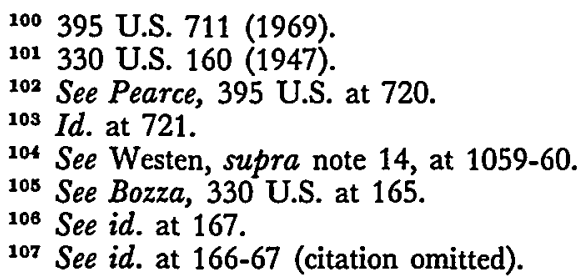


defendant was not in a gaming mood either when he challenged the sentence. Again, however, the Court viewed the initial unauthorized sentence as a legal nullity. One cannot argue double punishment when the Court refuses to recognize that there has been any punishment at all. ${ }^{108}$ The rule against increasing legal sentences when the initial conviction stands thus survives Bozza as well; the rule is concerned with initial sentences that are within statutory guidelines and thus cannot be considered legal nullities.

It is questionable, however, whether the multiple punishment protection of the defendant's interest in finality should be so flimsy that it cannot withstand the judicial fiction of Pearce and Bozza that the prior convictions and sentences never existed. The initial convictions and sentences certainly existed from the defendant's perspective. A defendant would see little difference between a situation in which an invalid sentence was imposed and later corrected and a situation in which a legal sentence has been imposed and later increased on remand. In both settings the original sentence has been increased, and the defendant's interest in finality has been violated.

This argument appears to be the rationale used by one commentator, who stated that "there is no substantive basis for distinguishing on multiple punishment grounds between the increase of a valid sentence ... and the increase of an invalid sentence ... . [I]n both instances the punishment initially imposed has been increased . . . ."109 But there are a number of practical reasons why the multiple punishment bar should treat these situations differently. The reasons become evident when one weighs the interests of the parties involved.

\section{Weighing the Interests in Resentencing}

As the DiFrancesco and Lange opinions show, the multiple punishment protection of the criminal defendant's interest in finality is not absolute-but neither is it nonexistent. To determine whether an alteration of a sentence should be barred by the multiple punishment rule it is useful to weigh the interests of the state against the interests of the defendant. The balancing of interests is not new for the Court in the

${ }^{108}$ Accord United States v. Henry, 709 F.2d 298, 308 (5th Cir. 1983) ("[T]he imposition of the initial sentence exceeded the court's statutory authority and was therefore a legal nullity.") (citation omitted).

109 Stern, Government Appeals of Sentences: A Constitutional Response to Arbitrary and Unreasonable Sentences, 18 AM. CRIM. L. REv. 51, 74 (1980) (footnotes omitted), quoted in United States v. Busic, 639 F.2d 940, 951 (3d Cir.), cert. denied, 452 U.S. 918 (1981). 
context of double jeopardy. ${ }^{110}$ As the Court noted in Burks v. United States, ${ }^{111}$ the defendant's interest in finality must be balanced against "society'[s] . . . valid concern for insuring that the guilty are punished."112

In the area of resentencing, the interest of the defendant is an interest in finality - a desire to have the ordeal of sentencing over once and for all and avoid the strain of uncertainty and delay. The defendant's interest is satisfied if, once a sentence is imposed, it may not later be increased.

The state has an interest in insuring that proper punishment is imposed for a particular offense and defendant. In the context of resentencing, there is no danger that the convicted defendant will go unpunished, since valid sentences are in force on the remaining counts and will be served regardless of whether resentencing is allowed. The state's interest thus involves a desire to avoid lenient sentences, not simply a desire to punish the guilty. A sentence on a particular count is "lenient" whenever the trial court would have imposed a greater sentence if it had known that other counts and sentences would be reversed on appeal.

The state also has an interest in keeping retaliatory motivations from playing a part in the sentence a criminal defendant receives. The defendant, of course, shares this interest in avoiding vindictive sentencing. The state's interest is actually another aspect of its desire to have a proper sentence imposed-an overly harsh, vindictive sentence is no better in this respect than a lenient sentence.

Before considering the balance of interests of the state and the defendant in the area of resentencing, it is helpful to examine the facts and interests in the Court's decisions regarding other alterations of initial sentences. In Lange the Gourt struck down an attempt by the sentencing judge to impose a new sentence after an authorized punishment for the offense had been fully served. ${ }^{113}$ In Bozza the Court held that an illegal sentence may be corrected even if the new sentence is harsher than the original sentence. ${ }^{114}$ In Pearce the Court held that a defendant whose conviction was overturned for trial error was subject not only to retrial but also to an increased sentence on retrial. ${ }^{115}$ Finally, in

110 See, e.g., United States v. Scott, 437 U.S. 82, $91-94$ (1978); Arizona v. Washington, 434 U.S. 497, 503-05 (1978); Illinois v. Somerville, 410 U.S. 458, 471 (1973);

United States v. Tateo, 377 U.S. 463, 466 (1964).

111437 U.S. 1 (1978).

112 Id. at 137 (citation omitted).

113 See Lange, 85 U.S. (18 Wall.) at 168.

114 See Bozza, 330 U.S. at 166-67.

115 See Pearce, 395 U.S. at 720. 
DiFrancesco the Court ruled that the government could appeal a sentencing decision pursuant to a specific federal statute granting it this power. ${ }^{116}$

In each of these cases the interests of the defendants were affected in the same way. Each defendant desired to have the sentence that was initially imposed become a ceiling-to avoid being placed once again in peril of the statutory maximum. Yet only in Lange did the defendant's. interest gain the protection of the Constitution. Since the effects on the defendants were so much alike, the dispositive factor in the balancing of interests in these cases appears to be the interests of the state.

The interests of the state in these cases were certainly dissimilar. Lange implicated the state's interest in preventing the imposition of illegal sentences. The new sentence imposed in Lange, if upheld, would have punished the defendant in excess of the maximum sentence allowed by statute. ${ }^{117}$ Bozza involved the state's interest in preventing illegal penalties and its interest in insuring that the guilty are punished. The latter interest was jeopardized because the defendant would go free if he could not be resentenced. ${ }^{118}$

In Pearce the Court noted that it followed from "[l]ong-established constitutional doctrine"119 that a court, following reversal of a conviction for trial error, could retry the defendant and impose a sentence longer than the defendant originally received. ${ }^{120}$ The interest of the state in this instance was to allow the court to function as a court: that is, to impose a sentence based on its perception of a fresh showing of facts and a fresh conviction. Finally, in DiFrancesco the state's interest was to fulfill the intent of Congress in establishing a "two-stage sentencing procedure."121 The DiFrancesco Court showed its reluctance to upset the intent of Congress by noting that the double jeopardy clause had never been used to invalidate an act of Congress. ${ }^{122}$

In the context of resentencing, the interest of the defendant is the same interest in finality as is found in these sentencing alteration cases. Again the defendant has an interest in being placed in peril of the maximum sentence only once for a particular offense. This interest is violated even if the sentencing judge decides not to increase the original sentence. It is the resentencing process that violates the defendant's finality interest, not merely the resulting increased punishment.

116 See DiFrancesco, 449 U.S. at 137-39.

117 See Lange, 85 U.S. (18 Wall.) at 175.

118 See Bozza, 330 U.S. at 166-67.

119 Pearce, 395 U.S. at 719.

120 See id. at 719-20.

121 DiFrancesco, 449 U.S. at 140 n.16.

122 See id. at 126. 
In turning to the weight of the interests of the state in resentencing to harsher punishment, it must first be remembered that the initial sentence is legal and that the underlying conviction has not been disturbed. As stated earlier, the state's interest under these circumstances is to avoid both lenient and vindictive sentences. The Pearce rationale does not apply in this setting, since resentencing does not involve a new trial with a fresh state of facts and a fresh conviction, which would warrant the corollary power to sentence to any lawful punishment. Also, unlike DiFrancesco, there is no statute expressing the legislature's desire to redefine finality. Finally, Bozza does not apply, since there is no illegal sentence to correct, and since the defendant will be punished even without a new sentence.

The state merely wishes to correct any possible mistake the judge may have made in sentencing. Its argument is simple. The judge could have initially imposed longer sentences on the remaining counts and stayed within statutory guidelines. Resentencing allows the judge to reapportion the original aggregate sentence to conform to her initial intentions. ${ }^{128}$ But this reapportionment comes at the cost of violating the defendant's finality interest and risking the possibility of vindictive sentencing. In addition, such a sentencing "mistake" could generally be avoided altogether by attaching sentences on the particular counts with a view to the gravity of that particular count and by adjusting the aggregate punishment by having some sentences run concurrently and some consecutively. ${ }^{124}$

128 One commentator has suggested that a rule barring resentencing "may produce extremely arbitrary sentencing outcomes." Stern, supra note 109 , at 76.

124 The problem and proper solution can best be seen in the context of an actual case. In United States v. Sales, 725 F.2d 458 (8th Cir. 1984), the defendant was convicted of ten separate counts of receiving stolen postal money orders and sentenced to "one year on count one, two years on count two, three years on count three, and so forth, through count ten, the sentences to run consecutively." Id. at 460 . The total sentence was thus fifty-five years. The unusually harsh sentence for receiving stolen property may have been motivated by the trial judge's desire to punish the defendant for not plea bargaining. See id. at $460 \&$ n.2. On appeal the Eighth Circuit held that the evidence was insufficient to show more than one illegal receipt of the money orders and reversed all but the first count. Id. at 460 .

Since the judge's sentencing plan had been changed from a 55-year sentence to a one-year sentence, it is clear that he would have imposed a greater sentence on the first count had he anticipated reversal of the other nine counts. Yet the judge's intent would not have been thwarted had he attached sentences commensurate with the gravity of each offense. Once the gravity of each offense has been established, a judge can adjust the aggregate sentence to reflect the gravity of the transaction. For example, a defendant who receives 20 stolen postal money orders does not necessarily deserve a 200 -year sentence. By using concurrent and consecutive sentences a judge can attempt to take into account the gravity of each offense as well as the gravity of the transaction. In this case the judge could have sentenced the defendant to ten years on each count, five to run consecutively and five to run concurrently, with a resulting 50-year term. After the 
Even when mistakenly lenient sentences cannot be avoided, to require that defendants sacrifice their interests in finality is to forsake a greater interest for a lesser: "The possibility of abuses inherent in broad judicial power to increase sentences outweighs the possibility of windfalls to a few prisoners." ${ }^{128}$ The defendant's constitutionally valued interest in finality and the state's interest in avoiding vindictiveness together withstand the interest of the state in correcting "mistakenly" lenient, albeit legal, sentences. ${ }^{128}$

\section{CONCLUSION}

The double jeopardy clause protects criminal defendants' interests in the finality of their sentences by prohibiting multiple punishments for the same offense. This protection restricts the judiciary's power to place a defendant twice in peril of the maximum legal penalty.

In order to avoid abuses of judicial power and respect the defendant's interest in finality, the multiple punishment bar must be read to prohibit the increase of a final legal sentence when the underlying conviction is maintained. A criminal defendant who has successfully appealed certain counts of a multicount conviction cannot be subjected to harsher sentences on the remaining counts without breaching the multiple punishment protection of the double jeopardy clause.

reversal of nine counts, the defendant would still serve the maximum 10-year term, and there would be no need for resentencing. If the judge believed that receipt of a stolen money order warranted the maximum allowable sentence, his intent would be fulfilled despite the reversal of the other nine counts.

Of course, a judge will not always be able to construct a sentencing scheme that takes into account the gravity of each offense, the gravity of the transaction, and the effects on his sentencing scheme of a reversal of some of the counts. The purpose of this example is to illustrate that mistakenly lenient sentences can often be avoided by the proper use of concurrent and consecutive sentences.

${ }_{125}$ United States v. Sacco, 367 F.2d 368, 370 (2d Cir. 1966); see also North Carolina v. Pearce, 395 U.S. at 731 n.3 (Douglas, J., concurring) ("The risk of judicial arbitrariness rests where . . . the Constitution puts it-on the Government.") (citation omitted).

${ }^{126}$ The American Bar Association's Standards for Criminal Justice also state that the power to increase a legal sentence would be "undesirable." STANDARDS FOR CRIMINAL JUSTICE $\$ 18-7.1$ commentary at 504 (1980). "Any such power would likely increase prisoner anxiety, [and] there would always be the possibility that such power would be misused ...." Id.; see also id. $\S 18-4.9$ (no increased sentences should be allowed in resentencing except in DiFrancesco situations). 